\title{
Duch, który cierpi. 0 roli cierpienia i rytuału w przeżywaniu kryzysów na przykładzie szkoły waldorfskiej
}

\begin{abstract}
Abstrakt
Tekst poświęcony jest roli rytuału i sztuki w pokonywaniu jednostkowego cierpienia i społecznych kryzysów. Choć niepopularny we współczesnej kulturze analgetyków, nastawionej na uzyskiwanie szybkich efektów, proces rytualny (jak pokazują za Turnerem Maria Mendel i Tomasz Szkudlarek), jest w swej istocie tożsamy z doświadczeniem kryzysu. Przechodzenie rytuałów ma więc potencjał transgresji, przekraczania sytuacji trudnych dla jednostek oraz społeczeństw. Omawiam to na przykładach przemian narracji porodowych oraz sposobów radzenia sobie z traumą przez Martina Millera, syna słynnej psychoterapeutki Alice Miller.

Inną cechą współczesnej kultury jest odrzucenie sacrum, co pokazuję na przykładzie usuwania teozoficznych wątków z biografii Marii Montessori i marginalizowania szkół waldorfskich Rudolfa Steinera, które wyrastają z kryzysu zachodniej racjonalności. Odtwarzane i zapośredniczone przez sztukę rytuały, wykorzystywane są w szkołach waldorfskich w celach wychowawczych i rozwojowych i zgodnie powyższymi teoriami mogą mieć potencjał pokonywania kryzysów związanych z dojrzewaniem.
\end{abstract}

Słowa kluczowe: cierpienie, kryzys, rytuał, sztuka, szkoła waldorfska, Rudolf Steiner.

\section{A Spirit that Suffers. The Role of Suffering and Ritual in Experiencing Crises through the Example of the Waldorf School}

\begin{abstract}
The text is devoted to the role of ritual and art in overcoming individual suffering and social crises. Although unpopular in the contemporary culture of analgesics, focused
\end{abstract}

Artykuł otrzymano: 14.07.2020; akceptacja: 3.11.2020. 
on achieving quick results, the ritual process (as Maria Mendel and Tomasz Szkudlarek show after Turner) is essentially identical to the experience of crisis. Therefore, going through rituals has the potential of transgression, and solving difficult situations for individuals and societies. I discuss this with examples of the changes in birth narratives and also showing the ways of dealing with trauma of Martin Miller, son of the famous psychotherapist Alice Miller.

Another feature of contemporary culture is the rejection of the sacrum, as illustrated by the removal of theosophical threads from Maria Montessori's biography and the marginalization of Rudolf Steiner's Waldorf schools, which stem from the crisis of Western rationality. Reproduced and mediated by art, rituals are used in Waldorf schools for educational and developmental purposes, and, according to the theories above, they may have the potential to overcome adolescence crises.

Keywords: suffering, crisis, ritual, art, Waldorf school, Rudolf Steiner.

\section{Wstęp}

$\mathrm{Na}$ początku pandemii koronawirusa otrzymałam telefon od Jerzego Prokopiuka - ezoteryka, tłumacza, literata zajmującego się gnozą, którego poznałam podczas badań etnograficznych nad ruchem społecznym antropozofów i edukacją waldorfską, które inicjował w Polsce (zob. Prokopiuk 1992, 2003, 1992). Rozmowa telefoniczna niosła przesłanie dla znajomych, których leciwy już gnostyk chciał pozytywnie natchnąć na zbliżający się, trudny czas społecznej izolacji wywołanej epidemią. Opracował więc kilka powodów, dla których warto przetrwać, oraz recept, jak zrobić to w spokoju ducha:

Po pierwsze - ciekawość, jak to się dalej potoczy i co się wydarzy (dla ludzi o mentalności naukowej);

Po drugie - to sprawdzian siły charakteru (czy rzeczywiście nikt i nic nie jest w stanie mnie złamać);

Po trzecie i czwarte - próba przejścia drogi od nienawiści i pogardy, do współczucia i litości;

Po piąte - poczucie humoru;

Po szóste - rozwijanie poczucia solidarności z innymi.

Porady te, a szczególnie punkty od drugiego do czwartego, bardzo mnie zaintrygowały. Drogę od nienawiści i pogardy, do współczucia i litości, interpretuję jako charakterystyczny scenariusz rozwoju duchowego i pracy nad sobą, stanowiącą podstawę każdej znanej mi myśli ezoterycznej. Dużo większym zaskoczeniem był dla mnie jednak punkt drugi - traktowanie pandemii jako przyczynku do sprawdzianu siły charakteru. Cierpienia, które uszlachetnia. Zdałam sobie sprawę, że bardzo rzadko słyszę dziś podobne sformułowania i zainspirowało mnie to do stawiania pytań o współczesną rolę i sens przeżywania cierpienia i kryzysu. 
Z listy wymienionej przez Prokopiuka można wywnioskować, że w praktykowanej przez niego filozofii ezoterycznej umiejętne przeżywanie trudności poprzez nadawanie im sensu pomaga przezwyciężać kryzysy - zarówno te osobiste związane z cierpieniem jednostki, jak i te rozumiane szerzej, kulturowo, jak doświadczenie pandemii. Czyli - inaczej mówiąc, odpowiednio przeżyte cierpienie czy trud może być kluczem do przekroczenia granic sytuacji kryzysu, czyli dokonania jego transgresji. To pojęcie w rozumieniu Józefa Kozieleckiego (Kozielecki 2002: 52) również może być rozumiane dwojako: jako transgresja typu P, czyli będąca przekraczaniem granic osobistych, oraz transgresja typu $\mathrm{H}$ - historyczna, o ważnym znaczeniu pozajednostkowym, istotnym dla ludzkości (tamże: 52). Czy można więc znaleźć inne, podobne do myśli Prokopiuka koncepcje, traktujące cierpienie jednostki i kryzys społeczny analogicznie? Jak wygląda to w praktyce badanych przeze mnie szkół waldorfskich wyrastających z filozofii ezoterycznej Steinera, bliskiej Prokopiukowi?

W tym krótkim tekście chciałabym przyjrzeć się kilku wybranym przykładom, które podejmują wątek przeżywania cierpienia i doświadczania kryzysu. Doprowadzą mnie one do analizy roli rytuału i duchowości w szkole waldorfskiej wyrastającej z antropozofii Rudolfa Steinera i będącej przedmiotem moich kilkuletnich badań antropologicznych. Nawiązując do formy, jaką przyjął Jerzy Prokopiuk, poprowadzę tę analizę w kilku krokach.

W pierwszym z nich - wprowadzającym, wyjdę od rozpoznania Leszka Kołakowskiego na temat analgetycznych właściwości kultury Zachodu, sytuującej cierpienie na marginesie kulturowych doświadczeń. Analizując jednak współczesne sposoby radzenia sobie z bólem i trudnościami, można zauważyć istotną w nich rolę rytualizacji i obrzędów przejścia. Wiąże się to z inspirującą tezą Marii Mendel i Tomasza Szkudlarka o strukturalnej tożsamości procesu rytualnego i przeżywania kryzysu. Cierpienie musi być więc rytualnie przeżyte, by poradzić sobie z kryzysem - nie ma na to jednak miejsca w kulturze analgetyków nastawionej na efekt, a nie proces.

Następnie na przykładzie interesującej historii psychoterapeutki Alice Miller i jej syna Martina Millera postaram się pokazać jedną ze współczesnych koncepcji psychologicznych, dostrzegającą wartość kryzysów osobistych w rozwoju jednostki i uznającą rolę współczesnych rytuałów w ich przechodzeniu. Jest to jednak realizacja w dużej mierze teoretyczna, bo ukazująca swoje słabości w praktyce wychowawczej Alice Miller, która sama nie przeszła tego procesu. Jednak świadomy i jawny sposób, w jaki jej syn Martin mierzy się z trudami dzieciństwa, pokazywać może jeszcze jeden aspekt dokonywania transgresji kryzysu - performatywne odtwarzanie go i zapośredniczenie przez sztukę.

W kroku trzecim podejmę wątek sacrum, które wiąże się z procesem rytualnym, jest jednak kategorią pozostającą w kryzysie w kulturze opartej na paradygmacie racjonalnym. Postaram się pokazać współczesne odchodzenie od związków 
z sacrum w edukacji. Odwołam się do pomijanych, teozoficznych wątków w biografii słynnej pedagożki Marii Montessori, a także pokażę to na przykładzie szkoły waldorfskiej opartej na filozofii ezoterycznej Rudolfa Steinera zwanej antropozofią (zob. Steiner 2005, 2004).

Na koniec omówię zrytualizowane sposoby przeżywania kryzysów, włączone w praktykę szkół waldorfskich, będących przedmiotem moich kilkuletnich badań. Pokażę rolę sacrum, szkolnych rytuałów, społeczności, sztuki i architektury we wspomaganiu pokonywania uczniowskich kryzysów, skoków rozwojowych.

Postaram się pokazać, że choć niepopularne w kulturze analgetyków waldorfskie wyrazy numinosum, odwołania do sacrum i rytuały oparte na strukturze Turnerowskich rites de passage, mogą pełnić ważną rolę $\mathrm{w}$ uśmierzaniu jednostkowego cierpienia oraz w pokonywaniu systemowych czy doświadczanych społecznie kryzysów. Zamiast „znieczulania bólu” stwarza się tu przestrzeń na rytualne i często artystycznie, performatywnie zapośredniczone przeżywanie trudności. Szkoła waldorfska wyrastająca z ezoterycznej myśli Steinera, sytuującej się w alternatywie wobec Zachodniej racjonalności, włącza do kultury szkolnej rytuał, sztukę i sacrum, wykorzystując je do osiągania celów wychowawczych i rozwojowych.

\section{Analgetyki i proces rytualny}

Współczesny stosunek do cierpienia nie jest jednoznaczny. W sytuacjach wyjątkowych, dotyczących świętości czy bohaterstwa, skłonni jesteśmy je gloryfikować. W życiu codziennym jednak robimy wszystko, by się go pozbyć. Leszek Kołakowski używał na określenie tego zjawiska medycznej metafory i nazwał kulturę współczesną - kulturą analgetyków:

Jeśli powiadam, że żyjemy w kulturze analgetyków, to mam na myśli nade wszystko te urządzenia cywilizacyjne, te formy obyczajowości i te sposoby współżycia, dzięki którym możemy źródła cierpienia maskować przed sobą, nie próbując ich ani usunąć, ani stawić im czoła (Kołakowski 2005: 137).

Jest to więc nie tyle realne pozbywanie świata bólu poprzez radykalne działania pomocowe, polityczne czy ekologiczne. To raczej działania pozorne: „maskowanie” go, udawanie, że go nie ma za pomocą leków, narkotyków, uciech cielesnych, rozrywek towarzyskich, pracy, wypieranie go z pola ludzkich doświadczeń, pozbawianie go widoczności. I nie chodzi tu o cierpienie spektakularne, którego obrazami bombardują nas media, prosząc o datek, po którego wpłaceniu czujemy się lepiej, jak po zażyciu środków przeciwbólowych. Chodzi o stopniowe, choć skuteczne wypieranie cierpienia oraz negatywnych emocji z przestrzeni medialnej, kulturo- 
wej, społecznej, a więc również edukacyjnej. Analgetyki znieczulają, jednak działają objawowo. Nie rozwiązują problemu, niwelują jedynie jego skutki. W kulturze analgetyków nie ma miejsca na rytuały, obrzędy i duchowość. Znieczulenie ma zastąpić wszelkie inne sposoby reagowania na kryzysy i zamiast integrować cierpienie w ludzkim doświadczeniu życiowym - neguje jego obecność. Zatem choć wciąż doświadczamy kryzysów, kult analgetyków pozbawia nas umiejętności radzenia sobie $\mathrm{z}$ trudnościami.

Jeśli więc pod koniec lat 60 . filozof mógł rozważać zagrożenia płynące z kultury niwelującej cierpienie, co powiedziałby dziś w obliczu zanikania nawet najbardziej błahych społecznych sposobów przeżywania cierpienia jak żałoba, czyli czas po stracie bliskiej osoby, gdy społecznie akceptowane jest manifestowanie smutku choćby poprzez np. czarny strój. Cierpienie czy nawet odmawianie sobie przyjemności jest wyrugowane z doświadczeń współczesności. Zaczynają być więc niwelowane obrzędy przejścia, które pozwalały radzić sobie z trudnościami w kulturowo uregulowanych ramach, czy odmawiać sobie przyjemności w celu przygotowania się na nowe. Coraz rzadziej (z powodów pozadietetycznych) celebrujemy post, który miał być ascezą, głodówką i przygotowaniem na czas jakościowy - karnawał. Śmieszy nas instytucja czystości przedmałżeńskiej będącej wyrzeczeniem przygotowującym na czas małżeńskich uciech.

Ciekawym przykładem pokazującym przemiany stosunku do cierpienia jest zmiana traktowania bólu porodowego. Porody przeszły niezwykłą kulturową ewolucję przez ostatnie sto lat - od czynności niemal codziennej, nieprzerywającej na zbyt długo cyklu życia i pracy, w którą wpisane wręcz było cierpienie fizyczne, poprzez radykalną medykalizację w PRL, do ponownej rytualizacji w duchu New Age. Wraz z modernizacją, porodowi utożsamionemu z zabiegiem medycznym, coraz częściej zaczęło towarzyszyć uśmierzanie bólu, znieczulanie, cesarskie cięcia usuwające do minimum jego fizjologiczny aspekt. Do świata rodzących wkroczyła kultura analgetyków. Upowszechnił się język i personel medyczny. Kobieta stała się „pacjentką”, babkę zastąpił lekarz, zmieniła się pozycja porodowa - z kucznej na wertykalną, umożliwiającą wykwalifikowanym osobom wygodniejsze „odebranie porodu” i obserwację krocza. 0 przemianach tych opowiada ciekawie zbiór wywiadów z położnymi - „Mundra” Sylwii Szwed. Autorka rozmawia z kobietami przyjmującymi dzieci na świat od przedwojnia, po dziś dzień. W wywiadzie z Teresą Tomczyk o jej pracy położnej w latach sześćdziesiątych pojawia się ciekawa wypowiedź:

Sylwia Szwed: Dziewczyny miały dużo mniej wiedzy, co się wydarzy w sali porodowej. Mamy przecież im nie mówiły, jak będzie.

Teresa Tomczyk: Z mojego doświadczenia wynika, że każda chciała wyjść na bohaterkę. Opowiadała, że tak jak ona rodziła, to żadna nie rodziła. Tak jak ją bolało, to absolutnie żadną. I to nie trwało pięciu godzin, tylko piętnaście (Szwed 2014: 114). 
Pomimo medycznych zabiegów narracje porodowe, tak jak klasyczne opowieści przygodowe, bywały dramatyzowane po to, by nadać przeżyciom rodzącej wyjątkowości, a ją samą ustawić w roli „bohaterki”. Cierpienie miało uszlachetniać, samo w sobie niosło jakości rite de passage, zmieniającego dziewczynę w kobietę, pannę w matkę, nadając jej nowy status o zabarwieniu etycznym.

Współczesne historie porodowe również wychodzą poza kulturę analgetyków i odżegnują się od nadmiernej medykalizacji, nie straszą już jednak cierpieniem. Świadomiej i mocniej podkreślają wagę rytualnego przeżywania porodu. Ból jest zaakceptowany, wpisany w doświadczenie egzystencjalne i traktowany jest jako nieodłączny element duchowego wymiaru obrzędu przejścia. Buduje się też nową, New Age-ową mitologię, w której główną rolę gra dzika matka rodząca z doulą, jednoczącej się ze swoją pierwotną kobiecą naturą, przynoszącą dziecko na świat w duchowej atmosferze, a ból nazywany jest metaforycznie falą, która otwiera.

Istotę włączania i doświadczeń trudnych czy kryzysowych w toku życia i oswajanie ich poprzez rytualizację dostrzegają pedagodzy Maria Mendel i Tomasz Szkudlarek. Piszą, że rytuały nie tyle pomagają w przeżywaniu trudności, są wręcz z nimi tożsame - są przeżywaniem kryzysu:

Spróbujemy rozwinąć myśl o kryzysie jako zjawisku nie tylko wpisującym się $\mathrm{w}$ logikę procesu rytualnego, ale $\mathrm{w}$ istocie będącym procesem rytualnym (Mendel, Szkudlarek 2013: 16)

- i dalej -

(...) kryzys jest zrytualizowaną formą wyrazu zmiany, zawsze po czymś i przed czymś; jest elementem opowieści, która musi się „dokonać” jako trudna do przeskoczenia sekwencja zdarzeń, która domaga się perypetii, rozpoznania i patosu - jeżeliby skorzystać z Arystotelesowskiej matrycy form wypowiedzi. Można pójść tą drogą i zobaczyć w kryzysie, jako narracji, składniki mythos - w szczególności w wersji fabuły tragicznej - z ważną funkcją katharsis (Mendel, Szkudlarek 2013: 20).

Ta propozycja podkreśla w przeżywaniu kryzysu rolę procesu rytualnego czy też obrzędu przejścia, ze wszystkimi swoimi trzema fazami opisanymi przez Turnera: „fazą separacji, fazą marginalizacji (albo liminalna od limen, co oznacza „próg” po łacinie) oraz fazą włączenia" (Turner 2010: 115). Co więcej, wręcz zrównuje je $\mathrm{z}$ tym procesem. Każde więc przeżywanie procesu rytualnego jest kryzysem, transgresją typu $\mathrm{P}$ - bądź w przypadku wydarzeń o globalnym znaczeniu - typu $\mathrm{H}$. Co za tym idzie, aby dokonać przekroczenia, transgresji czy ekspansji w światy potencjalne (Kozielecki 2002: 87), należy przeżyć kryzys - czyli przejść proces rytualny i przeżyć katharsis. Stąd uszlachetniająca rola cierpienia doświadczanego wskutek przeżywania pandemii wymieniona przez Jerzego Prokopiuka. 
Mendel i Szkudlarek (Mendel, Szkudlarek 2013: 20) zauważają też performatywną funkcję przeżywania kryzysu. Może być on rodzajem narracji, nowej mitologii, która przynosi oczyszczenie. Słowem, rytuał może być również wymyślany, odprawiany, odgrywany, aranżowany - i w ten sposób przeżywany.

\section{Alice i Martin Miller - kryzys, psychoterapia i sztuka}

Gdzie jeszcze można spotkać koncepcje, które dostrzegają sens rytualnego przeżywania cierpienia, doświadczania trudności bądź przechodzenia kryzysów i ich transgresji? Przyjrzyjmy się jednej z najbardziej wpływowych pozycji wychowawczych wydanych w Polsce w 1995 r. przez Jacka Santorskiego - Dramat udanego dziecka autorstwa psycholożki i terapeutki Alice Miller. To opublikowana oryginalnie w 1979 r. jako Das Drama des begabten Kindes radykalna propozycja antyprzemocowa, stawała po stronie dziecka i doszukiwała się źródeł zaburzeń depresyjnych i manii wielkości w przemocy fizycznej i niespełnianiu dziecięcych potrzeb przez rodziców. Bestseller ten sytuował źródło problemów osobowościowych i wychowawczych w nieakceptowaniu przez rodziców dziecięcych trudnych emocji. Jak pisze Miller:

Właśnie w tym oczywistym i naturalnym dostępie do własnych uczuć i pragnień człowiek odnajduje swoją siłę i szacunek do siebie. Wolno mu być smutnym, zrozpaczonym lub bezradnym i nie obawiać się, że kogoś wyprowadzi to z równowagi. Wolno mu bać się, kiedy czuje się zagrożony, wolno mu odczuwać złość, kiedy nie może zaspokoić swoich pragnień. Nie tylko wie, czego nie chce, ale również czego chce, i wyraża to niezależnie od tego, czy jest za to kochany czy nienawidzony (Miller 2007: 39).

Brak akceptacji tych emocji ze strony rodziców, negowanie ich, zabranianie dzieciom przeżywania ich i przez to - niespełniania swoich emocjonalnych potrzeb, prowadzi według Miller do zaburzeń wielkościowych, których rewersem jest depresja. Dzieci starają się zrekompensować rodzicom to, że są nieidealne poprzez osiąganie sukcesów i budowanie wizerunku „wielkiego człowieka”, a przez to - samookłamywanie się. Gdy jednak sukcesy przychodzą z trudnością, łatwo popaść w kolejną skrajność - depresję, czyli wyparcie „własnych reakcji emocjonalnych i odczuć”, którego celem jest „niezbędne dla zachowania życia przystosowanie, wynikające z lęku przed utratą miłości w dzieciństwie” (tamże: 47). Kultura współczesna jawi się tu jako kultura dwubiegunowa, którą charakteryzuje luka pomiędzy euforią wywoływaną sukcesem a skrywaną i odrzucaną depresją, powodowaną porażką.

W jaki sposób poradzić sobie z tym kryzysem? Lukę tę ma wypełniać współczesny obrzęd przejścia - psychoterapia, umożliwiająca świecką ceremonię bez- 
piecznego, asystowanego przeżycia trudnych emocji w gabinecie terapeuty. Psychoterapia ma ułatwić performatywne przeżycie trudności z pełną mocą Schechnerowskiego dramatu społecznego ujawniającego się na „scenie”. Ma to być przeżycie współczesnego katharsis - czyli litości i trwogi umożliwiających uwolnienie się od emocjonalnych trudności i ograniczeń. Innymi słowy - rytualne przejście punktu trzeciego z listy Jerzego Prokopiuka.

To bardzo ciekawe w kontekście ostatnich dyskusji o spuściźnie Miller, z którą już po jej śmierci rozlicza się jej syn Martin, sam będący psychoterapeutą. W wydanej w 2013 r. pozycji Das wahre „Drama des begabten Kindes”. Die Tragödie Alice Millers (wydanie polskie: Martin Miller, Prawdziwy „dramat udanego dziecka”, 2015) obnaża błędy wychowawcze własnej matki, oskarża ją o emocjonalny chłód, a ojca naznacza jako sprawcę domowej przemocy. Odkrywa fakty biograficzne skrywane przez samą terapeutkę, a dotyczące jej traumatycznej młodości, gdy jako Żydówka ukrywała się pod zmienionym nazwiskiem w okupowanej Warszawie, w ciągłym lęku przed śmiercią i dekonspiracją. Do Szwajcarii wyjechała wraz z przyszłym mężem Andrzejem-Andreasem dopiero w 1946 r. na stypendium, dzięki któremu uzyskała doktorat. Rola jej męża jest w narracji Martina Millera dość niejednoznaczna, a postać Alice Miller naznaczona hipokryzją, gdyż nie potrafiła przepracować własnej tragedii, co doprowadzić miało do odrzucenia własnego dziecka i serii wychowawczych błędów, które zarzucała innym rodzicom w swoich książkach. Martin Miller rozwija te wątki w filmie Who is afraid of Alice Miller („Kto się boi Alice Miller”) z 2020 r., reklamowanym hasłami „Podróż w wypieraną traumę matki” czy „W poszukiwaniu własnych korzeni”, gdzie wraz z rodziną, terapeutami i socjologami odwiedza współczesną Warszawę i przeczesuje archiwa w celu odkrycia sekretów słynnej matki i przepracowania w ten sposób urazów z dzieciństwa, które wiąże z transgeneracyjnym dziedziczeniem traumy i „tragedią strukturalną spowodowaną przez wojnę i Holocaust" (Who is afraid...).

Sposób, w jaki Martin Miller radzi sobie z kryzysem wywołanym postawą matki, wymaga uwypuklenia. Niezależnie od moralnej oceny jego postępowania i pytania o czysto materialną naturę jego pobudek, warto zauważyć środki, jakie wykorzystuje, by poradzić sobie z traumą. Odrzuca kulturę analgetyków. Nie wypiera trudności i ich nie ukrywa, tylko włącza je w swoje doświadczenie życiowe, przeżywa je, rytualnie zabierając widzów w „Podróż w wypieraną traumę” - nie tylko matki, lecz i swoją, a nawet w duchu transgresji typu $\mathrm{H}$ - kulturową, w odniesieniu do Holocaustu. Co więcej, zapośrednicza swoje doświadczenie przez sztukę i literaturę. Film i książka mają pełnić tu rolę terapeutyczną, obrzędową, pomagającą w zmierzeniu się z cierpieniem i bólem, w celu uwolnienia się od nich i dokonania, za Kozieleckim, osobistej transgresji typu P - przejścia jakościowej przemiany na lepsze.

Powyższy przykład pokazuje, że koncepcja Alice Miller, choć niezwykle atrakcyjna teoretycznie, ukazała swoją słabość w zastosowaniu w praktyce wychowaw- 
czej autorki. Jej własna teoria nie pomogła psychoterapeutce w dokonaniu przekroczenia sytuacji kryzysowej. Aby poradzić sobie z traumą, Martin Miller zmierzył się z cierpieniem, postanowił je przeżyć i zintegrował je we własnym egzystencjalnym doświadczeniu. Sięgnął również po inne środki i podjął się innych, pozapsychologicznych praktyk w celu uśmierzenia własnego bólu. Można więc zastanawiać się, czego zabrakło w propozycji Alice Miller, że choć dostrzegała wartość odtwarzania procesu rytualnego $\mathrm{w}$ gabinecie psychoterapeuty, nie była w stanie uporać się ze swoim własnym cierpieniem i obarczyła nim swego syna. Czy nie uległa czasem analgetycznemu złudzeniu, że będąc medialną figurą, wolna jest od żmudnego przechodzenia przez bolesny proces rytualny w celu transgresji kryzysu?

\section{Niebezpieczne związki szkoły i sacrum. Osobny Steiner i teozoficzna Montessori}

Elementem nierozłącznym z procesem rytualnym jest sacrum. Próby wprowadzania go do współczesnych instytucji życia społecznego wiążą się zazwyczaj z krytyką jako nieprzystające do współczesnej racjonalności. Warto jednak w tym kontekście odnieść się do społecznej i kulturowej roli sacrum. W reakcji na słabość struktur regulujących może ono wprowadzać to, co Znaniecki nazywał ładem aksjonormatywnym. Jak pisze za Durkheimem Elżbieta Tarkowska, sacrum może przejąć funkcję porządkującą świat w dobie jego kryzysu - stanu, który sama nazywa chaosem kulturowym (Tarkowska 1993a: 34). Tarkowska analizuje przede wszystkim przypadek przełomu demokratycznego w Polsce, pokazując reakcje społeczne na ten kryzys - zawężenie czasu i miejsca społecznego (myślenie krótkoterminowe, ograniczona mobilność), tworzenie małych grup, powrót do produkcji naturalnej i wymiany bezgotówkowej, a także wzrost zabobonności czy też myślenia magicznego i w rezultacie powrót do sacrum (Tarkowska 1993b: 90). Czyli - przejście Turnerowskiej fazy drugiej, czyli separacji, marginalizacji - fazy liminalnej. Podobne tendencje i zachowania wykazują ruchy społeczne i grupy funkcjonujące w ramach kultury alternatywnej, gdyż pojawiają się one właśnie w reakcji na kryzys instytucji normotwórczych w kulturze głównego nurtu (Cantril 1963: 63).

W ruchach tzw. szkół alternatywnych pojawiają się propozycje włączania różnorako rozumianych przejawów duchowości do kultury szkoły. Pozostają one zawsze w krytycznej relacji względem szkół wyrastających z paradygmatu naukowego. Powoduje to, że związki szkoły i sacrum są uznawane za niepopularne oraz ryzykowne dla naukowej recepcji myśli pedagogicznej. Odwoływanie się do pozaracjonalnych, duchowych inspiracji stoi w sprzeczności wobec zachodniej racjonalności na podobnej zasadzie, jak przechodzenie bolesnego procesu rytualnego, które nie mieści się w nastawionej na efekt, a nie proces kulturze analgetyków. Dlatego szkoły odwołujące się do sacrum są często poddawane krytyce, a nieracjonalne 
wątki w biografiach słynnych pedagogów owiane są milczeniem. By zyskać znaczenie w świecie sceptycznym wobec duchowości, zjawiska z obszaru sacrum muszą zostać przyobleczone w profanum albo zgodzić się na dryf na marginesach kultury.

Przedmiotem moich badań etnograficznych w Polsce i w Berlinie były szkoły waldorfskie odwołujące się do filozofii ezoterycznej Rudolfa Steinera zwanej antropozofią. Interesowała mnie przede wszystkim funkcja sacrum w szkole, a także funkcja szkoły odwołującej się do sacrum w kulturze polskiej lat 80. i 90.

Szkoły waldorfskie pojawiły się w Polsce w jako efekt jednego z ważniejszych kulturowych kryzysów współczesności - przemiany ustrojowej związanej z przełomem demokratycznym. Wkroczyły na fali edukacyjnych i społecznych przemian, które nazywam za Zbigniewem Kwiecińskim społecznym ruchem edukacyjnym i którego forpocztą były znane w całej Polsce szkoły społeczne zakładane przez nauczycieli i rodziców w ramach Społecznego Towarzystwa Oświatowego (STO). Kryzys ten, którego kulturę opisuje świetnie Elżbieta Tarkowska, rozwijając koncepcję chaosu kulturowego (Tarkowska 1993: 34), dawał dobry grunt dla zjawisk o ezoterycznym podłożu, gdyż charakteryzował się osłabieniem dotychczasowych struktur porządkujących świat, a tym samym zwrotem ku sacrum, duchowości, rozwojem zachowań zabobonnych, co w praktyce skutkowało m.in. modą na New Age. Mimo to szkoła waldorfska zawsze pozostawała tworem osobnym ze względu na swoją niemiecką genezę, związki z wątpliwą i niezrozumiałą z punktu widzenia polskiej, katolickiej duchowości antropozofią oraz silne nastawienie ekologiczne, które pozostawało w sprzeczności z kapitalistycznymi fantazjami młodej polskiej demokracji. Jej duchowy aspekt, choć przystający do kultury kryzysu lat 80/90., budził zbyt wiele zastrzeżeń i niebezpiecznych skojarzeń (m.in. z niemieckim romantyzmem, duchowymi podstawami ideologii nazistowskiej czy też zwyczajnie rozbudzając kompleks niższości wobec zachodniej, wolnościowej koncepcji pedagogicznej), by mógł stanowić centrum edukacyjnej awangardy.

Ze względu na swój stosunek do sacrum, szkoła waldorfska pozostawała na obrzeżach nurtu zmian, czy mówiąc językiem Turnera, w obszarze marginalnym, liminalnym. To szkoła rodząca się $\mathrm{w}$ wyniku kryzysu racjonalności, a więc odtwarzająca strukturę tego kryzysu, co odbija się w kulturze szkoły. Jej osobność to trend, który utrzymuje się od jej zarania, czyli od założenia przez Rudolfa Steinera (na zaproszenie fabrykanta Emila Molta) pierwszej szkoły waldorfskiej w Stuttgardzie w 1919 r. Choć powstanie szkoły waldorfskiej splata się chronologicznie z ruchami Nowego Wychowania w Europie Zachodniej i jest wpisywane w nurt Niemieckiej Pedagogiki Reformy, zazwyczaj jej rola wymaga przypisu. Jędrzej Sobczak, opisując rozwój ruchów Nowego Wychowania, wytycza za Rogerem Cousinetem w ich ramach podział na trzy nurty: „mistyczny”, „filozoficzny” i „naukowy”, z tym, że jedynie tym dwóm ostatnim przyznaje „poważny udział w formowaniu się teorii i praktyki Nowego Wychowania" (Sobczak 1998: 20). Poważny, czyli jaki? Przede wszystkim pozbawiony elementów duchowości. 
Sobczak, broniąc przedmiotu swoich naukowych zainteresowań, polemizuje ze Stefanem Kunowskim, który chciał doszukiwać się w sformułowaniach budujących zasady powstałej w 1921 r. w Calais Międzynarodowej Ligi Nowego Wychowania르, ezoterycznych inspiracji.

Wyrażenia „siła ducha” czy jej wyzwolenie pojmowano - pisze S. Kunowski - jako wydobywanie specjalnych sił duchowych o charakterze metapsychicznym, jak siła nadzwyczajna woli, hipnotyzerstwo, telepatia, jasnowidzenie, mediumizm i okultyzm. S. Kunowski sugeruje, że Międzynarodowa Liga Nowego Wychowania była „ekspozyturą masonerii” i wprowadzała do swoich założeń światopogląd towarzystw masońskich: ezoteryczny mistycyzm propagowany przez teozofię Heleny Bławatskiej i Rudolfa Steinera (tamże: 34).

Dalej Sobczak wysubtelnia i wyjaśnia:

pomyłki i tendencyjne interpretacje w odniesieniu do Nowego Wychowania wynikały z tkwiących w nim niedomówień, tajemnic („mystiques”). Brały się one z nie całkiem jednoznacznego określenia koncepcji filozoficznej, na której opierał się nowy kierunek wychowawczy, a również z niedomówień na temat struktury społecznej, jakiej miał służyć. Filozofia J. J. Rousseau bliska bezsprzecznie Nowemu Wychowaniu u początków XX w., ukierunkowana naturalistycznie, dawała różne możliwości interpretacji, min, wywodzenia proponowanych działań wychowawczych z przesłanej filozofii spirytualistycznej (Sobczak 1998: 34).

Im dalej więc od duchowości utożsamianej z mistyką - tym lepiej.

W podobnym stylu przedstawia relacje ezoteryki i Nowego Wychowania polsko-francuska reżyserka Joanna Grudzińska, w swoim filmie dokumentalnym Szkolna rewolucja 1919-1939² z 2016 r. Pokazuje ona ruchy edukacyjne w duchu radykalnego przewrotu, powołującego nową antropologię:

Nowoczesna pedagogika narodziła się tak naprawdę po I Wojnie Światowej. Jej celem było pełne zrozumienie dziecka i wychowanie nowego, wolnego człowieka, który nie będzie powtarzał już krwawych błędów swych rodziców. Totalitaryzmy położyły kres tej utopii, ale wypracowane

\footnotetext{
1 Za: Liga Nowego Wychowania (1931): „1. Istotnym celem wszelkiego wychowania jest przygotować dziecko do tego, aby pragnęło urzeczywistnić w życiu supremację ducha nad materią: trzeba zatem, aby wychowanie bez względu na to, jakie by były skądinąd poglądy wychowawcy, dążyło do zachowania i potęgowania sił duchowych dziecka. 2. Wychowanie powinno szanować osobowość, może zaś się ona rozwinąć tylko dzięki systemowi, który prowadzi do wyzwolenia potencjalnych sił duchowych dziecka, a wolność jest pierwszym tego warunkiem" (tamże: 463).

2 Por.: Rewolucja Szkoła: 1918-1939 (1939).
} 
wówczas ambitne idee odżyły kilka lat później i pomogły stworzyć nowe, wykorzystywane do dziś, sposoby wychowywania oraz uczenia dzieci. (Szkolna rewolucja...).

Reżyserka przybliża najważniejszych pedagogów współtworzących środowisko, a także skupia się na postaci emblematycznej dla Międzynarodowej Ligi Nowego Wychowania - lekarce Marii Montessori. Pracująca pierwotnie z dziećmi upośledzonymi umysłowo Włoszka stała się ikoną ruchu uprawomocniającą jego założenia siłą nauk przyrodniczych. Jak pisze Sobczak:

Około 1907 roku M. Montessori w przedszkolu, a Owidiusz Decroly w szkole elementarnej wypróbowują na dzieciach normalnych metody i organizację pracy stosowane w czasie zajęć z dziećmi anormalnymi. (...) Niektórzy pedagodzy akcentują fakt, że ruch Nowego Wychowania wyszedł nie tylko z grona pedagogów „uwięzionych” w ich biurokratycznych instytucjach, lecz był inspirowany przez lekarzy i psychologów (Sobczak 1998: 26).

To, co ma w tej narracji zaświadczać o wartości Nowego Wychowania, to właśnie status lekarki prowadzącej eksperymenty naukowe z wykorzystaniem "metod” i osiąganie mierzalnych efektów.

Joanna Grudzińska w swym dokumencie poświęca kilka chwil również Rudolfowi Steinerowi, którego przedstawia jako postać osobną (rzeczywiście nigdy nie został członkiem Międzynarodowej Ligi Nowego Wychowania), pozostającą na uboczu przemian i dość dziwną. Podkreśla to w filmie reżyserskimi zabiegami, takimi jak wykorzystanie abstrakcyjnej, cyfrowej muzyki i animowanych elementów graficznych, egzotyzujących szkoły Steinera i podkreślających wrażenie inności. Mistycyzm Steinera nie przystaje do naukowości Montessori. Szkolna rewolucja ma zrywać więc z „krwawymi błędami swych rodziców”, jednak nie z nowoczesną racjonalnością i prymatem nauk ścisłych.

Narracja ta nie jest jednak wolna od zgrzytów i nieciągłości, a wybór Marii Montessori na ikonę zachodniej racjonalności obarczony jest poważnym ryzykiem, tkwiącym w biografii samej lekarki. Montessori była związana z Towarzystwem Teozoficznym. Ostatnie dziesięć lat swojego życia (1939-1949), wraz ze swoim synem Mario, spędziła w Indiach. Jako obywatelka Włoch została internowana z powodu wybuchu II Wojny Światowej i przebywała w teozoficznym centrum w Adyarze na zaproszenie Geaore'a Arundale ${ }^{3}$. Jak pisze Carolie Wilson z Uniwersytetu w Sidney, niektóre źródła podają, że Montessori została członkinią Towarzystwa Teozoficznego już w 1899 r. (Wilson 1985: 52-54). Sami teozofowie piszą, że przyjaźń lekarki i Annie Besant, przewodniczącej Towarzystwa Teozoficznego, zaczęła się w roku 1907, pierwsze artykuły dotyczące jej pedagogiki, które powsta-

\footnotetext{
3 Por. Maria Montessori, https://theosophy.wiki/en/Maria_Montessori\#Involvement_with_Theosophists
} 
ły w ich środowisku, datowane są na 1913 r., a eksperymentalna, żeńska klasa montessoriańska została założona przez nich w Madrasie w 1918 r. ${ }^{4}$ Fragmenty archiwalnych filmów, przedstawiające ją w towarzystwie Besant są nawet ukazane w dokumencie Joanny Grudzińskiej, która nie przeczy związkom Montessori z ezoterykami, choć równolegle prowadzi narrację przedstawiającą pedagogikę Steinera jako ezoteryczne kuriozum.

Montessori zapytana w czasie wojny, czy jest teozofką, miała odpowiedzieć wymijająco „jestem Montessorianką” (Wilson 1985: 52-54). Twórca pedagogiki waldorfskiej - Rudolf Steiner, też nie zwał się teozofem, choć początki jego ezoterycznej działalności to właśnie kierowanie niemiecką sekcją Towarzystwa Teozoficznego. Jeszcze przed 1913 r. nastąpiło jednak zerwanie Steinera i teozofów i powołanie przez niego własnego towarzystwa głoszącego konkurencyjną myśl filozoficzno-ezoteryczną - antropozofię, która rozciągała się na różne sfery życia - od stosunku do uprawy ziemi czy produkcji leków, do duchowego podejścia do edukacji (Steiner 2005). Kto wie, czy osobność szkół Steinera i nurtów pedagogicznych obecnych w łonie Międzynarodowej Ligi Nowego Wychowania nie wynikała właśnie z wcześniejszego konfliktu na poziomie organizacji o modnym wówczas $\mathrm{w}$ inteligenckich kręgach charakterze wtajemniczeniowym, a sięganie przez teozofów do pedagogiki Montessori, a nie Steinera nie miało charakteru gry o wpływy.

Związki ruchu Nowego Wychowania i ezoteryków są dziś, jeśli nie zapomniane, to przynajmniej niepodkreślane. Relacje szkoły i sacrum to często temat niewygodny. Rysem charakterystycznym kultury analgetyków i wyrastającej z niej współczesnej edukacji jest kryzys duchowości i prymat umysłu. Tym bardziej ciekawe jest więc przyjrzenie się, jak wykorzystuje przejawy sacrum i rytuały szkoła, która zbudowana jest na filozofii ezoterycznej (nawet jeśli jej współczesne realizacje niejednokrotnie wolałyby odciąć się od tych korzeni i pozostawać jedynie waldorfskimi, ale już nie steinerowskimi).

\section{Szkoła waldorfska - sacrum i rytuał}

Sfera obrzędowości i rytualizacji jest istotna w szkołach waldorfskich, które były przez ostatnie lata obszarem moich badań antropologicznych. Metodyka waldorfska opiera się na antropozofii Rudolfa Steinera, a więc na ruchu myślowym

\footnotetext{
4 Por. tamże. Co ciekawe, nie tylko teozofowie z Adyaru zainteresowani byli Nowym Wychowaniem. Lokalne, polskie koło teozoficzne również szukało kontaktu z postępowymi pedagogami. Piszą o tym w tekście o historii polskiej teozofii Izabela Trzcińska, Agata Świerzowska i Józef Szymeczek: „Od samego początku członkowie Polskiego Towarzystwa Teozoficznego uznawali pedagogikę i różne formy pracy z młodzieżą za ważną dziedzinę swoich działań. Szczególnym zainteresowaniem cieszyła się popularna w środowiskach teozoficznych pedagogika Marii Montessori. Planowano nawet otwarcie nowatorskiej szkoły, nie udało się jednak doprowadzić tego pomysłu do końca. Janina Karasiówna współpracowała z Heleną Radlińską (1879-1954), którą zapraszano na spotkania teozoficzne dotyczące wychowania" (Trzcińska, Świerzowska, Tomeczek 2019: 97).
} 
i społecznym wyrastającym ze zwrotu ku duchowości charakterystycznego dla kultury fin de siècle w Europie Zachodniej.

Szkoły waldorfskie stanowią dziś międzynarodowy ruch zglokalizowanych (tworzonych w oparciu o lokalne tradycje i zwyczaje, lecz wciąż odwołujących się do wspólnego duchowego źródła) placówek społecznych czy prywatnych. Jednym z istotnych wyróżników tych szkół jest próba włączenia pierwiastka duchowego do kultury szkoły i - jak wynika z moich badań - wykorzystanie go w dwóch podstawowych celach: regulatywnym i wychowawczo-rozwojowym.

Jak dyscyplinuje rytuał i architektura? Sacrum, atmosfera duchowości, której przejawy w szkole waldorfskiej to m.in. rozbudowane rytuały, święta, ale również odpowiednia gra światłocienia w budynkach, wystrój i architektura, przejmują funkcje porządkujące. Nie ma tu ocen liczbowych, a budynki szkolne dekorowane i meblowane są w taki sposób, by odwoływać się do metafory świątyni, a nie jak choćby w przypadku popularnych w Polsce szkół typu „tysiąclatki”, wojskowych metafor koszar czy fabryki (Nalaskowski 2002: 79).

Jak twierdzi Peter McLaren w książce Schooling as a ritual performance, rytuały występują w każdym typie szkoły, budując jej kulturę. Każdy kto przekracza szkolny próg, musi stosować się do obowiązujących tam zasad (np. nie biegamy, pukamy do drzwi, czekamy na korytarzu, zwracamy się odpowiednio do personelu). Co istotne i zbieżne z ropoznaniami Mendel i Szkudlarka, McLaren podkreśla, że już samo wypełnianie rytuału oznacza jego akceptację, czyli poddanie się jego przymusowi. Dotyczy to nawet tych sytuacji, gdy nie jest on sprawowany z wiarą czy przekonaniem (McLaren 1999: 132).

W kulturze waldorfskiej można obserwować wręcz rozrost wspólnotowych rytuałów. Widać to w strukturze waldorfskiej lekcji głównej (codziennej porannej dwugodzinnej lekcji, na której w systemie trzymiesięcznym realizowane są podstawowe przedmioty szkolne), która zaczyna się od szeregu zabiegów mających wyrazić numinosum: zapalenia świecy, recytacji spokojnym głosem, wyciszenia. W szkole waldorfskiej w Berlinie, gdzie prowadziłam dwutygodniową obserwację etnograficzną, uczniowie wiedzą, kiedy nastąpią po sobie kolejne etapy lekcji, kiedy będą śpiewać, kiedy ustawiać ławki, kiedy lekcja zbliża się do końca. Rytuał dyscyplinuje, powtarzany codziennie staje się przyzwyczajeniem i bez słów reguluje, a nawet automatyzuje uczniowskie zachowanie.

Choć w Polsce, inaczej niż w Niemczech, nie ma szkół waldorfskich zbudowanych wedle zasad architektury organicznej i mieszczą się one zazwyczaj w zaadaptowanych na cele szkolne budynkach, można tam również zauważyć elementy wystroju czy dekoracje, które mają wyrażać to, co Rudof Otto nazywa numinosum i budować atmosferę wzniosłości (Otto 1993). Dlatego pełno tam fizycznych przedstawień sacrum: obrazów i rzeźb aniołów i odniesień kosmicznych, rysunków planet, znaków zodiaku. Ściany każdej z klas pomalowane są pastelowymi kolorami zgodnie z waldorfską, a zaczerpniętą z goetheanizmu nauką o kolorach - Farbenlehre. 
W rogach klas lekcyjnych są zaaranżowane kąciki - wystawki z chust, kwiatów, figurek i rzeźb, w bardzo charakterystycznej waldorfskiej estetyce, odpowiadające porom roku czy świętom. Funkcje numinotyczne przejawia też waldorfska architektura organiczna, którą miałam okazję zaobserwować choćby w Rudolf Steiner Schule w Berlinie, nawiązująca do popularnej w Niemczech secesji (Jugendstil) i niemieckiego ekspresjonizmu, dziś coraz bardziej uwspółcześniana, z domieszką na nowo odczytywanego modernizmu. Wrażenie wzniosłości potęguje kolorystyka, półmrok czy wykorzystanie światła naturalnego, użyte oświetlenie. To wszystko sprawia, że szkoła nabiera kontemplacyjnych cech bliskich budynkom sakralnym, więc odpowiednio dyscyplinuje i wpływa na zachowanie. Budzi to zastrzeżenia sceptyków, dostrzegających w tak wysubtelnionych zabiegach potencjał manipulacji zachowaniem dziecka.

Architektura szkół waldorfskich chce holistycznie angażować różne zmysły człowieka. Pełno więc tam naturalnych materiałów, różnorodnych tekstur, rozwartych kątów, nieregularnych okien, budujących wrażenie inności i wybijających nas z tradycyjnych, architektonicznych przyzwyczajeń. Tego typu zabiegi ciekawie komentuje fiński architekt Juhani Pallasmaa w książce Oczy skóry. Pisze on, że współczesna architektura oraz kultura w ogóle są nazbyt okulocentryczne, czyli skupione na bodźcach wzrokowych, a „nadmierna koncentracja na intelektualnych, konceptualnych aspektach architektury przyczynia się do zaniku jej fizycznego, zmysłowego i cielesnego charakteru" (Pallasmaa 2012: 41). Wpływa to na osłabienie tego, co nazywa on materialnością budynków. Może być to jednak powstrzymane przez używanie materiałów naturalnych, bliskich człowiekowi, bo poddających się podobnym co on procesom starzenia się i przemiany. Tworzywa sztuczne natomiast nie ujawniają swojej „materialnej istoty” i skrywają swój wiek, mamiąc nas obietnicą nieśmiertelności. Jak pisze Pallasmaa: „ten lęk przed śladami zużycia czy starzenia wiąże się z naszym lękiem przed śmiercią" (tamże: 40).

To bardzo bliskie waldorfskiej koncepcji metamorfozy, która odnoszona na homeopatycznej zasadzie simile (podobieństwa, ale też odpowiedniości procesów zachodzących w mikro- i makrokosmosie): od rośliny, przez organizm człowieka, do budynków zakłada, że wszystkie one mają podlegać podobnym prawom i procesom narodzin, rozwoju, starzenia się i obumierania. Ważne jest więc pochodzenie materiałów, historia użytkowania, patyna czasu. W pedagogice waldorfskiej opartej na antropozoficznej wierze w reinkarnację, nabieranie doświadczenia i starzenie się są ważne jako bagaż wiedzy i doświadczeń umożliwiających rozwój. Holistyczna wizja świata chce wpisywać człowieka w naturalne kontinuum oparte na przemianie, dlatego architektura manifestuje swoją materialność, poddaje się działaniu czasu, i nie dryfuje ku „pewnej dystansującej, schładzającej, desensualizacji i deerotyzacji związku człowieka z rzeczywistością" (tamże: 41). Architektura szkół waldorfskich ma więc pobudzać wiele zmysłów i operować narzędziami pozwalającymi na przekroczenie dominacji wzroku. Chropowatość drewna, chłód cienia, 
oślepiająca jasność światła są tu równouprawnionymi środkami wyrazu. To dlatego architektura tych szkół stawia na organiczność form, naturalną estetykę pomieszczeń, na detale architektoniczne wprowadzające odpowiedni nastrój, a tym samym regulujące i modelujące zachowanie ucznia.

\section{Obrzędy i rytuały o funkcji wychowawczo-rozwojowej w szkole waldorfskiej}

Rytuały w szkole waldorfskiej stosowane są jednak nie tylko po to, by dyscyplinować i wpływać na zachowanie w sposób niewyrażony wprost, lecz przynależny do ukrytego programu szkoły. Rytuał - jak w rozumieniu Mendel i Szkudlarka - ma spełniać pomocniczą rolę w przechodzeniu kryzysów, a więc we włączaniu doświadczeń trudnych i cierpienia w doświadczenie egzystencjonalne dziecka i pomaganiu mu w dokonaniu transgresji. Spełnia więc funkcję wychowawczą, a także rozwojową, gdyż - zgodnie z teorią Turnera, faza ponownego włączenia wiąże się ze zmianą statusu (Turner 2010: 115).

Przyjrzymy się więc tego typu rytuałom wpisanym w cykl dzienny i roczny szkoły waldorfskiej, a także aranżowanym za pośrednictwem sztuki - narracji bądź zaaranżowanego przez rodziców performansu. Idąc za przywołanym powyżej rozpoznaniem McLarena oraz arystotelowskimi odwołaniami u Mendel i Szkudlarka, taka steatralizowana forma, choć „sztuczna”, również uruchamia myślenie mityczne, które ma prowadzić do katarktycznego oczyszczenia, przejścia na wyższy poziom. Tak samo jak w przypadku opisywanych powyżej nowych narracji porodowych, terapeutycznych czy jak w przypadku leczenia dziecięcej traumy Martina Millera - cierpienie nie jest tu wyrugowane $\mathrm{z}$ dziecięcego doświadczenia, lecz zostaje oswojone poprzez towarzyszącą mu społeczność, rytualizację jego przeżywania, włączenie pierwiastka duchowego do kultury szkoły i zapośredniczenie przez sztukę.

Rytuały w szkole waldorfskiej są częścią małego cyklu, jakim jest pojedynczy szkolny dzień czy tydzień w szkole, ale również cyklicznie rozumianego roku szkolnego czy całościowego szkolnego doświadczenia, będącego długim, dwunastoletnim cyklem rozwojowym. Waldorfskie założenia wychowawcze zostały oparte na holistycznej, antropozoficznej wizji rozwoju jednostki ludzkiej, która bardzo szczegółowo określa, co dzieje się z człowiekiem pod względem rozwoju jego fizyczności czy osobowości podczas czterech pierwszych siedmioleci rozwoju i radzi, w jaki sposób zapewnić mu prawidłowe wsparcie. Dlatego ważne w rozwoju dziecka są skoki rozwojowe, momenty graniczne, nazywane poetycko „przejściami Rubikonu", które wymagają szkolnych rites de passage, pomagających w bezpiecznym przedostaniu się na kolejny etap rozwojowy. Pierwszy z nich występuje około dziewiątego roku życia, kolejne w klasach szóstej i dziesiątej. Wtedy, jak powiadają 
pedagodzy waldorfscy, dzieci przechodzą od wiary, że świat jest dobry, przez dostrzeganie, że świat jest piękny aż do zrozumienia, iż jest on prawdziwy. Ryty te uwzględniane są w różnorodny sposób w programie szkolnym - dobiera się odpowiednie opowieści, odgrywa się sztuki teatralne przedstawiające bohaterów, na których uczniowie mogą się wzorować, a nawet dobiera się ćwiczenia geometryczne dające poczucie stabilności tak, by pomóc dziecku w bezpiecznym przedostaniu się na kolejny etap rozwoju.

Bardzo ważne dla osiągnięcia celu wychowawczo-rozwojowego, z którego powodu wprowadza się do szkoły waldorfskiej sacrum, jest częste, wspólnotowe obchodzenie świąt. W języku niemieckim używa się wręcz sformułowania „Monatsfeier”, czyli święto comiesięczne. Najważniejsze są cztery okazje przypadające na cztery pory roku: wiosną: Wielkanoc, latem: Święto Janowe, jesienią: Święto Marcinowe, zimą: Boże Narodzenie. Szkoła waldorfska w Poznaniu proponuje jednak również celebrowanie innych okazji w każdym z miesięcy:

Miesiące jesienne: wrzesień (Św. Michał), październik (Dożynki), listopad (Św. Marcin, święto lampionów) - miesiące darów jesieni, darów ziemi. Miesiące zimowe: grudzień (Adwent, Św. Mikołaj, Kiermasz Świąteczny, Jasełka, Boże Narodzenie), styczeń (Trzech Króli, Dzień Babci i Dziadka), luty (Balik Karnawałowy). Miesiące wiosenne: marzec (Wiosenne Święto Szkoły), kwiecień (Kiermasz Świąteczny, Wielkanoc), maj (Zielone Święta, Dzień Rodziny). Miesiąc letni: czerwiec (Dzień Rodziny, Św. Jan) (Organizacja pracy świetlicy).

Szkoły waldorfskie mają w swym programie różnorodne aktywności artystyczne z okazji świąt, jednak przynajmniej kilka z nich traktowanych jest jako momenty, w których mogą dokonać się rytuały przejścia. Wykorzystuje się w tym celu opisane już powyżej i rozpoznane przez Rudolfa Otto techniki wyrazu numinosum - światło, cień, zapala się świeczki budujące atmosferę magii i tajemnicy, stosuje się lejące się, miękkie materiały, a także muzykę i pieśni, które mają za zadanie zbudować nastrój podniosłości i wzniosłości, oraz stanowić spektakl umożliwiający przeżywanie silnych emocji - oczekiwania, lęku, niepokoju, zaskoczenia, podziwu, radości.

Jednym z przykładów obrzędów odbywających się w cyklu rocznym może być waldorfski sposób obchodzenia dnia św. Marcina 11 listopada. Dzieci przygotowują z tej okazji przedstawienia teatralne czy wieczór opowieści poświęcony celebrowaniu gestu św. Marcina będącego symbolem uczucia litości, którą okazał bogaty święty ubogiemu żebrakowi:

Jak co roku wysłuchamy opowieści o Świętym, co pochylił się nad niedolą żebraka i płaszczem go swoim otulił. Jak co roku zapalimy lampiony, światełkami i śpiewaniem rozjaśnimy listopadowe ciemności. Może znów uda nam się spotkać jeźdźca na koniu? A może nawet uda nam się jak Marcinowi, kogoś poratować? (Święto Marcinowe). 
W krakowskiej szkole waldorfskiej na ul. Zwiłej przedstawienie to ma charakter atrakcyjnego wizualnie, tajemniczego performansu. Dzieci przez kilka dni w oczekiwaniu na święto kleją bibułowe lampiony, z którymi wreszcie wychodzą na rozległe przyszkolne błonia, śpiewając powolną, medytacyjną wręcz pieśń: „Święty Marcin, święty Marcin, jedzie błoniem, siwym koniem. A po pustym błoniu, sroga zima goni. Jedzie, jedzie święty Marcin na swym siwym koniu...”. W wieczornej szarówce pojawia się jeździec na białym koniu, który macha zamaszyście płaszczem i zostawia pod drzewem tajemniczy worek. Zanim dzieci dobiegają do skraju łąki - jeździec znika. W worze znajdują jednak dar: Marcińskie, słodkie rogale, które przynoszą do szkoły:

Najpierw teatr - opowieść o św. Marcinie - mężnym i współczującym rycerzu, potem poszukiwanie i spotkanie z rycerzem na siwym koniu, który pojawił się z mgły i we mgle rozpłynął, ale... zostawił worek pełen rogali. Po powrocie do dworku smakowaliśmy przepyszny kompot i rogale (Święty Marcin).

Oprócz tradycyjnego waldorfskiego spektaklu przygotowanego przez dzieci oraz spaceru z lampionami, które same w sobie są elementami rytualnymi, wyrażającymi numinosum, dodany jest tu także element dramatyczny przygotowany przez dorosłych. Właściciel szkoły, Marek Sołek, przedsiębiorca i właściciel „Szkoły Kaskaderów Filmowych 13", zatrudnia do odegrania sceny na koniu jednego ze swoich kaskaderskich uczniów.

Rodzice i nauczyciele często angażowani są do przygotowywania dla dzieci wizualnych performansów służących waldorfskiej obrzędowości. W szkole waldorfskiej im. A. Cieszkowskiego w Warszawie z okazji Jarmarku Adwentowego rodzice przygotowali dla dzieci grotę gnoma i jezioro wróżek, aranżując na szkolnym korytarzu labirynt z chust, lampek i przezroczystych paciorków. Światła wiodły dzieci przez niskie korytarze, prowadząc do pokoiku - groty wróżki z ołtarzykiem, na którym stał lichtarzyk, szklana kula, gdzie leżały poduszki „kreując magię", jak nazwała to jedna z matek (Kreowanie magii...). Zamieściła w internecie film pokazujący kulisy przygotowania labiryntu oraz dokumentujący, jak jej rozemocjonowane dziecko biegnie przez labirynt, a ona porozumiewa się z nim szeptem, respektując podniosłą atmosferę panującą $\mathrm{w}$ przepełnionej sacrum konstrukcji.

O podobnej konstrukcji zaciemnionej groty, przez którą przechodziły dzieci w jednym z przedszkoli waldorfskich, opowiadała mi nauczycielka przedszkolna i właścicielka przedszkola Ziarenko w Krakowie. Grota powstała z okazji Wielkanocy, a wchodzące tam dzieci znajdowały w czeluściach sadzonkę hiacynta. Wychodziły z nią potem na światło dzienne z drugiej strony konstrukcji, a następnie sadziły roślinkę i opiekowały się nią, zyskując nową odpowiedzialność. W opowieści nauczycielki przejście dziecka przez grotę miało korespondować z przemianą, którą 
dokonuje roślina w cyklu rocznym - od zimowego uśpienia pod ziemią, przez kiełkowanie, po wyjście na świat i rozkwit. Skojarzenia mogą oscylować również wokół historii zmartwychwstania Chrystusa, a symbolika groty jest tu jak najbardziej znacząca i swą strukturą ewokuje klasyczny rite de passage. W waldorfskim cyklu rocznym znajduje się więc wiele okazji, by oprócz codziennych rytuałów angażować dzieci również w obrzędy przejścia, które symbolizują dojrzewanie i rozwój dziecka, a także przemianę świata w dorocznym cyklu natury.

Struktura takiego obrzędu, opisana przez Turnera, polega na przejściu przez trzy fazy: preliminalną, wyrażającą się w separacji i wyłączeniu z dotychczasowego stanu (w przypadku wielkanocnej groty - wejściu do ciemności), liminalną czy okres marginalny, przejściowy (przebywanie w grocie, znalezienie sadzonki) oraz postliminalną polegającą na ponownym włączeniu do społeczności (wyjście z groty), ale już na nowych zasadach (zasadzenie sadzonki, stanie się starszym, odpowiedzialnym przedszkolakiem) (Turner 2010: 115). Wejście dziecka do ciemnej groty może wiązać się z niecierpliwym oczekiwaniem, ale również z lękiem przed ciemnością i atmosferą sacrum. Wydarzenie to jest tak zaprojektowane, by było rodzajem przygody (choć wiadomo, co jest po drugiej stronie), prowadzącej do rozwoju poprzez zapośredniczone przez sztukę, udramatyzowane przejście procesu rytualnego.

Szkoła waldorfska jest więc szkołą powstałą w wyniku kryzysu racjonalności w powojennej rzeczywistości Europy Zachodniej w 1919 r. W Polsce pojawiła się również $\mathrm{z}$ momencie chaosu kulturowego - w czasie przemian demokratycznych 1989 r. Odpowiada więc na sytuacje kryzysowe, oferuje jakości, które są wtedy pożądane. Sama też zawsze jest osobna i pozostająca na marginesie ruchów edukacyjnych (w obszarze liminalnym). W swojej kulturze odtwarza i odbija cechy kultury kryzysu opisane przez Tarkowską: zwrot ku małej społeczności, obecność sacrum, zwrot ku naturze, rzemiośle, sztuce i rytuałom. Poprzez powtarzające się w cyklu rocznym performatywne przechodzenie procesu rytualnego chce „uzdrowić" swoją społeczność z sytuacji kryzysowej, wspomóc uczniów w momentach skoków rozwojowych i umożliwić przejście, transgresję i oczyszczającą przemianę.

\section{Podsumowanie}

Kultura Zachodu ma niejednoznaczny stosunek zarówno do cierpienia, jak i do duchowości. Z jednej strony ból i ofiara są podziwiane i gloryfikowane, a duchowość przyobleczona we wpływowe politycznie instytucje. Z drugiej, gros wysiłków kultury Zachodu skupionych jest na rugowaniu cierpienia i bólu z doświadczeń ludzkich, a nauka i rozwój zachodniej racjonalności sytuują się w opozycji do nieweryfikowalnej nauki duchowej. Cierpienie powinno być tu jednak rozumiane zarówno jako doświadczenie jednostki (transgresja typu P), ale też jako szersze 
doświadczenia kulturowe (transgresja typu H) - kryzysy, które wstrząsają światem z niezawodną regularnością. Scenariusz doświadczania i transgresji jednych i drugich wydaje się być jednak powtarzalny zarówno na poziomie mikro (jednostkowym), jak i makro (społecznym, kulturowym). Kiedy chwieje się dotychczasowy porządek, wkraczać zaczyna alternatywna racjonalność. Gdy zawodzi medycyna konwencjonalna - wkracza medycyna tradycyjna. Gdy sypie się system edukacji - wkracza szkoła alternatywna. Gdy zawodzą systemy polityczne - wkraczają ruchy społeczne. Wiele z nich oferuje sacrum jako Durkheimowską zasadę, nadającą sens i porządkującą doświadczenie, a więc pozwalającą na uporanie się z kryzysami i zbudowanie nowego świata.

W dostępie do sacrum pomagają rytuały, które umożliwiają transgresję - przekroczenie granic i przejście $\mathrm{z}$ jednego stanu do drugiego. Im bardziej kultura Zachodu jest ich pozbawiona $\mathrm{w}$ imię analgetycznej racjonalności, tym bardziej odżywają one w przyczółkach kultury alternatywnej, jak szkoły waldorfskie. Można tam, choćby w steatralizowanej formie, doświadczyć tego, co pozaracjonalne i jak piszą Mendel i Szkudlarek - przeżyć kryzys jako proces rytualny (Mendel, Szkudlarek 2013: 16). Szkoły te podkreślają wagę rites de passage, edukacyjne znaczenie wyrażania się w pozaracjonalnym języku sztuki czy przeżywanie czasu świątecznego, jakościowego dla rozwoju i dojrzewania. Ma to znaczenie w pokonywaniu rozwojowych i społecznych trudności czy w budowaniu szkolnej struktury społecznej z wykorzystaniem porządkującej funkcji rytuału.

W kulturze Zachodu obie narracje - racjonalna i pozaracjonalna występują równolegle, a nawet by zdobyć znaczenie i zyskać siłę sprawczą, zjawiska z obszaru sacrum muszą ustąpić, skapitulować wobec profanum. Bo w paradygmacie racjonalnym nie ma miejsca na rytuały, obrzędy i duchowość, lecz jednocześnie brak systemowej umiejętności reagowania na kryzysy i integrację cierpienia w ludzkim doświadczeniu życiowym. Oba nurty, jak naziemna i podziemna rzeka, funkcjonują więc w naszej kulturze równolegle i oddziałują na nas symultanicznie. Z jednej strony zapewniając nam bezpieczeństwo poznawcze, jakie niesie prymat umysłu, z drugiej zaskakując nas nieweryfikowalną skutecznością tego, co pozaracjonalne, w przeżywaniu i łagodzeniu cierpienia i przechodzeniu kryzysów kultury.

\section{Bibliografia}

Cantril H. (1963) The Psychology of Social Movements, New York, John Wiley \& Sons, Inc.

Kołakowski L. (2005) Obecność mitu, Warszawa, Prószyński i S-ka.

Kozielecki J. (2002) Transgresja i kultura, Warszawa, Wydawnictwo Akademickie „Żak”. 
McLaren P. (1999) Schooling as a ritual performance. Toward a Political Economy of Educational Symbols and Gestures, Boston, Rowman \& Littlefield Publishers.

Liga Nowego Wychowania (1931), „Przegląd Pedagogiczny”, nr 21.

Miller A. (2007) Dramat udanego dziecka, tłum. N. Szymańska, Poznań, Media Rodzina.

Miller M. (2015) Prawdziwy „dramat udanego dziecka”, tłum. K. Kumpf, Kraków, Oficyna Wydawnicza „Impuls”.

Nalaskowski A. (2002) Przestrzenie i miejsca szkoły, Kraków, Oficyna Wydawnicza „Impuls”.

Otto R. (1993) Świętość. Elementy irracjonalne w pojęciu bóstwa i ich stosunek do elementów racjonalnych, tłum. B. Kupis, Wrocław, Wydawnictwo Thesaurus Press.

Pallasmaa J. (2012) Oczy skóry. Architektura i zmysły, tłum., M. Choptiany, Kraków, Wydawnictwo Instytut Architektury.

Prokopiuk J. (2003) Szkice antropozoficzne. Chrześcijańska droga poznania świata duchowego, Białystok, Wydawnictwo Studio Astropsychologii.

Prokopiuk J. (red.) (1992) Wychowanie bez lęku. Pedagogika Steinerowska, Warszawa, Wydawnictwo Społeczne Towarzystwo Oświatowe.

Sobczak J. (1998) „Nowe wychowanie” w polskiej pedagogice okresu Drugiej Rzeczypospolitej (1918-1939), Bydgoszcz, Wyższa Szkoła Pedagogiczna w Bydgoszczy.

Steiner R. (2004) Zagadnienie wychowania jako zagadnienie społeczne. Duchowe, kulturowo-historyczne i społeczne podłoża pedagogiki Szkoły Waldorfskiej, tłum. E. Łyczewska, Gdynia, Wydawnictwo Genesis.

Steiner R. (2005) Duchowe podstawy sztuki wychowania. Wykłady oksfordzkie, tłum. E. Łyczewska, Gdynia, Wydawnictwo Genesis.

Szwed S. (2014) Mundra, Wołowiec, Wydawnictwo Czarne.

Tarkowska E. (1993a) Próby - Chaos kulturowy w: Kulturowy wymiar przemian społecznych, A. Jawłowska, M. Kempny, E. Tarkowska (red.), Warszawa, Polska Akademia Nauk, s. 31-38.

Tarkowska E. (1993b) Temporalny wymiar przemian zachodzacych $w$ Polsce w: Kulturowy wymiar przemian społecznych, A. Jawłowska, M. Kempny, E. Tarkowska (red.), Warszawa, Polska Akademia Nauk, s. 87-100. 
Trzcińska I., Świerzowska A., Tomeczek J. (2019) Z dziejów polskiej teozofii w: Polskie tradycje ezoteryczne 1980-1939. Teozofia i antropozofia, Tom I, Gdańsk, Wydawnictwo Uniwersytetu Gdańskiego.

Turner V. (2010) Proces rytualny. Struktura i antystruktura, tłum. E. Dżurak, Warszawa, Państwowy Instytut Wydawniczy.

\section{Źródła internetowe}

Hess K. M., George Arundale, http://www.tradycjaezoteryczna.ug.edu.pl/node/845, 16.01.2020 [dostęp: 8.07.2020].

Kreowanie magii w Szkole Waldorfskiej. Grota Gnoma. Jezioro Wróżek. \#OkiemMAtkiSłowianki, https://youtu.be/R-IZgcj4AzI [dostęp: 18.06.2020].

Maria Montessori, https://theosophy.wiki/en/Maria_Montessori\#Involvement_with _Theosophists [dostęp: 7.07.2020].

Mendel M., Szkudlarek T. ( 2013), Kryzys jako dyskurs i narracja. Konteksty edukacyjne, w: „Forum Oświatowe, 3 (50), s. 13-34, http://forumoswiatowe.pl/index.php/ czasopismo/article/view/163 [dostęp: 19.06.2020].

Organizacja pracy świetlicy, http://www.waldorfska.org/swietlica/ [dostęp: 18.06.2020].

Rewolucja Szkoła 1918-1939, https://u-jazdowski.pl/kino/repertuar/rewolucja-szkola -1918-1939 [dostęp: 7.07.2020].

Szkolna rewolucja 1918-1939, https://www.planeteplus.pl/dokument-szkolnarewolucja-1918-1939_47128 [dostęp: 7.07.2020].

Święto Marcinowe, http://www.waldorfskaszkola.pl/aktualnosci/wpis/82/SwietoMarcinowe [dostęp: 17.06.2020].

Święty Marcin, http://www.szkolawaldorfska.pl/aktualno\%C5\%9Bci [dostęp: 17.06.2020].

Who is afraid of Alice Miller?, https://www.whosafraidofalicemiller.com/en\# protagonisten [dostęp: 10.06.2020].

Wilson C. (1985) Montessori was a Theosophist, „History of Education Society Bulletin", vol. 36, s. 52-54, http://www.kelpin.nl/fred/download/montessori/english/ theosophist.pdf [dostęp: 7.07.2020]. 